Syntax Fusion : Jurnal Nasional Indonesia

e-ISSN : 2775-4440

Vol. 1, No. 9, September 2021

\title{
FUNGSI KERUKUNAN KELUARGA KALANG (K3) DALAM ASPEK SOSIAL EKONOMI DI DESA AMBALKEBREK KECAMATAN AMBAL
}

\author{
Putri Anggraeni \\ Universitas Negeri Semarang \\ Email: putrisosant@gmail.com
}

\begin{abstract}
Abstrak
Masyarakat Kalang identik dengan bentuk rumah yang besar melambangkan kebangsawanannya, melakukan ritual, slametan, sajen, dan bersifat tertutup dengan masyarakat. Kalang tidak dapat hanya mempertahankan institusi tradisionalnya karena kebutuhan menjadi semakin kompleks mengikuti kemajuan jaman. Kalang di Desa Ambalkebrek kecamatan Ambal memiliki pemikiran yang modern dengan membentuk K3 (kerukunan keluarga kalang), akan tetapi K3 membawa dampak pada relasi baru di masyarakat. K3 dan masyarakat dalam aspek sosial bersifat terbuka dengan adanya anggota K3 yang menjadi kepala desa, dan keberadaan keluarga Kalang (K3) sangat dihormati dengan pemberian panggilan nganten (ningrat). K3 dan masyarakat dalam aspek ekonomi melakukan kerjasama, dalam menjalankan bisnis wirausaha $K 3$ banyak mempekerjakan masyarakat setempat.

Metode yang digunakan dalam penelitian ini adalah metode penelitian kualitatif. Penelitian ini mengambil lokasi di Desa Ambalkebrek Kecamatan Ambal Kabupaten Kebumen. Fokus penelitiannya adalah (1) fungsi kerukunan keluarga kalang (K3) dalam hubungan sosial di Desa Ambalkebrek Kecamatan Ambal Kabupaten Kebumen, (2) fungsi kerukunan keluarga kalang (K3) dalam hubungan ekonomi di Desa Ambalkebrek Kecamatan Ambal Kabupaten Kebumen, (3) pentingnya koperasi K3 untuk relasi dan pertukaran antara pihak patron kalang dan klien masyarakat Desa Ambalkebrek Kecamatan Ambal Kabupaten Kebumen. Metode pengumpulan data yang digunakan adalah observasi, wawancara mendalam, dan dokumentasi. Keabsahan data dilakukan menggunakan teknik triangulasi dengan pemeriksaan dan pemanfaatan sumber. Analisis data dilakukan dengan analisis interaktif.
\end{abstract}

Kata Kunci : Masyarakat Kalang, K3, Aspek Sosial Ekonomi

\section{Pendahuluan}

Masyarakat Kalang banyak terdapat di Jawa Tengah yaitu Gombong, Ambal, Petanahan, Puring, Cilacap, Majenang, Maos, Adipala, Kroya, dan Yogyakarta. 
Masyarakat Kalang di Ambal melalui perkawinan memiliki keturunan dari kerajaan Pengging, keraton Solo, dan keraton Yogyakarta.

Masyarakat Kalang menurut mitos dari masyarakat Desa Ambalkebrek Kecamatan Ambal Kabupaten Kebumen, adalah keturunan dari Bandung Bondowoso dan Roro Jonggrang. Bandung Bondowoso mempunyai kelakuan yang jelek yaitu sering memerkosa perempuan sehingga mendapat kutukan menjadi seekor anjing. Bandung Bondowoso bertemu dengan seorang putri yaitu Roro Jonggrang yang sedang menenun. Roro Jonggrang tidak mau mengambil alat tenunnya yang jatuh ke tanah kemudian melakukan sayembara, "Barang siapa yang bersedia mengambil alat tenunnya, apabila perempuan maka akan diangkat saudara dan apabila laki-laki maka akan diangkat menjadi suami”. Bandung Bondowoso mengambil alat tenun itu dan kemudian diangkat menjadi suami. Roro Jonggrang memiliki anak dengan Bandung Bondowoso. Anak itu suatu ketika membunuh ayahnya sendiri dan membakarnya. Masyarakat Kalang terbagi menjadi 2 istilah yaitu Kalang Obong (dari garis keturunan laki-laki) dan Kalang Kamplong (dari garis keturunan perempuan) karena adanya pembakaran jazad dari Bandung Bondowoso. Masyarakat Kalang yang diobong adalah keturunan laki-laki karena dipercaya memiliki sifat seperti Bandung Bondowoso.

Kalang menurut E. Ketjen (dalam Warto, 2011: 5), merupakan masyarakat yang mengambil bagian dalam pembangunan tempat-tempat suci agama Budha yang megah tetapi ketika agama Budha surut profesi masyarakat Kalang yang semula menjadi tukang batu berubah menjadi tukang kayu dan penebang hutan. Masyarakat Kalang menduduki kelas terendah dalam masyarakat saat itu. Masyarakat Kalang yang disebutkan oleh Ketjen di atas berbeda dengan masyarakat Kalang sekarang khususnya yang berada di Desa Ambalkebrek Kecamatan Ambal. Masyarakat Kalang di Desa Ambalkebrek sekarang ini menduduki status sosial yang tinggi karena menjadi majikan dalam usaha-usaha ekonomi yang dikembangkan K3.

Kalang bersifat tertutup dan terbatas dalam bersosialisasi dengan masyarakat tetapi sekarang dengan perubahan jaman kelompok Kalang berusaha menyesuaikan diri dengan pemikiran yang modern. Kalang yang hanya menjadi tuan tanah dalam sistem feodal, identik dengan bentuk rumah yang besar melambangkan kebangsawanannya, melakukan slametan dan ritual lainnya, tetapi Kalang sekarang tidak cukup hanya melakukan hal tersebut. Kalang memiliki kebutuhan yang semakin kompleks mengikuti kemajuan jaman. Kalang membutuhkan bentuk baru yang modern sebagai penyesuaian jaman agar keberadaannya diakui di masyarakat.

Kerukunan Keluarga Kalang (K3) adalah fakta yang menunjukkan adanya bentuk penyesuaian baru Kalang di tengah masyarakat yang terus mengalami kemajuan. K3 merupakan suatu bentuk organisasi yang telah tersusun secara sistematis kepengurusannya. Anggota K3 adalah khusus orang-orang yang mempunyai keturunan raja, meskipun bukan keturunan raja tetapi menikah dengan Kalang maka dapat masuk menjadi anggota K3. Tujuan dibentuk K3 yaitu mempererat tali persaudaraan, saling tolong menolong untuk ekonomi lemah, menyelesaikan masalah intern dalam keluarga 
Kalang, menjaga serta menghormati K3. Anggota K3 di Desa Ambalkebrek mencapai jumlah 61 kepala keluarga.

Masyarakat Kalang dengan membentuk K3 membawa dampak pada relasi dengan masyarakat. Masyarakat Kalang dan masyarakat umum dalam aspek sosial sudah membaur dan bersifat terbuka sehingga tidak dapat lagi dikatakan bersifat individualis. Kalang membutuhkan adanya kerjasama dengan masyarakat. Keluarga Kalang sangat dihormati di masyarakat yaitu dipanggil dengan embel-embel Nganten (nama ningrat), dan adanya anggota K3 yang menjadi kepala desa sehingga memperlihatkan bahwa kelompok Kalang mampu memberikan kepercayaan kepada masyarakat. Masyarakat terutama yang menjadi pekerjanya lebih memilih kepala desa dari keluarga K3.

Kerukunan Keluarga Kalang (K3) dan masyarakat dalam aspek ekonomi banyak melakukan bisnis wirausaha, seperti jasa angkutan umum dan truk, usaha home industri seperti gula jawa dan emping, serta usaha kecil lannya. K3 juga membutuhkan tenaga kerja untuk memasarkan hasil produksinya. K3 dan masyarakat setempat yang menjadi tenaga kerja memiliki hubungan timbal balik. Masyarakat bekerja dengan giat untuk mendapatkan imbalan atau upah dari anggota K3, sedangkan anggota K3 membutuhkan pekerja untuk menjalankan usahanya tersebut.

K3 pada awalnya hanya mengadakan kegiatan arisan dan pertemuan rutin khusus keluarga Kalang, tetapi sekarang sudah berkembang dengan membangun koperasi K3 yang khusus untuk anggota K3 dan sudah berbadan hukum. Anggota K3 dapat memanfaatkan layanan simpan pinjam koperasi untuk mengembangkan usahanya. Anggota koperasi K3 yang sejahtera dan mampu mengembangkan usahanya maka akan membutuhkan pekerja yang lebih banyak. Masyarakat tidak dapat menikmati layanan simpan pinjam di koperasi, tetapi masyarakat khususnya yang menjadi pekerja dapat meminjam uang kepada tuan atau majikannya. K3 memberikan sesuatu yang diharapkan masyarakat, kemudian menimbulkan kewajiban untuk membalas kebaikan tersebut, yang disebut dengan hubungan patron klien.

\section{Metode Penelitian}

Metode yang digunakan adalah metode penelitian kualitatif. Penelitian ini memberikan penjelasan dan menceritakan tentang aktivitas dan program K3, serta aspek sosial ekonomi K3 dengan masyarakat. Penelitian ini menghasilkan data deskriptif berupa kata tertulis atau lisan seperti hasil wawancara, dan keberadaan K3 di masyarakat seperti hubungan antara K3 dengan sesama keluarga Kalang, K3 dengan masyarakat setempat, dan K3 dengan masyarakat yang menjadi pekerjanya.

Pemilihan lokasi di Desa Ambalkebrek Kecamatan Ambal Kabupaten Kebumen, karena pada lokasi tersebut merupakan desa yang jumlah orang Kalang lebih banyak dibandingkan desa lain di Kecamatan Ambal, selain itu lokasinya dekat dengan Koperasi K3, terdapat usaha angkutan umum K3, dan beberapa usaha perekonomian K3 lainnya. Dusun di Desa Ambalkebrek yang dihuni oleh keluarga Kalang adalah Dusun Kalicilik, Dusun Kuneman, dan Dusun Kebrek. 
Sumber Data PenelitianPenelitian ini mengambil sebagian keluarga di Desa tersebut, adapun keluarga yang diambil sebagai subjek penelitian berjumlah 5 orang anggota K3, dan 2 orang yang menjadi pekerja anggota K3 Desa Ambalkebrek Kecamatan Ambal Kabupaten Kebumen. Penulis tidak mengalami kesulitan dalam mencari anggota K3 yang dapat dijadikan subjek penelitian karena K3 sudah mempunyai kepengurusan yang jelas. Penulis justru mengalami kesulitan ketika menentukan pekerja K3 yang dapat dijadikan subjek penelitian, karena itu penulis memilih pekerja yang lama mengabdi dan dapat memberikan informasi dengan jelas. Penulis dalam melaksanakan penelitian lebih dekat dengan ketua K3 yaitu Sugeng Diyono dan pekerja anggota K3 yaitu Satemi dan Saringan.

Penulis selama berada di lapangan mendapatkan data dari buku koperasi K3 dan catatan tentang silsilah keluarga K3. Penulis mendapatkan buku koperasi K3 dari ketua K3, sedangkan catatan tentang silsilah keluarga K3 didapatkan sewaktu penulis mengikuti acara Halal Bi Halal K3.

Observasi pertama kali dilakukan pada tanggal 19 Maret 2011. Observasi dilakukan dengan tinggal selama 1 bulan di lokasi penelitian. Penulis melihat langsung proses produksi yang dilakukan oleh pekerja $\mathrm{K} 3$ dari usaha home industri seperti emping mlinjo dan gula jawa. Penulis juga ikut dalam pemasaran hasil produksi dari usaha home industri tersebut di wilayah Kecamatan Ambal. Penulis menghadiri acaraacara rutin yang diselenggarakan oleh K3, seperti acara Halal Bi Halal, arisan K3, kegiatan koperasi K3, dan lomba pacuan kuda. Penulis membantu dalam pengambilan foto selama acara-acara tersebut berlangsung.

\section{Hasil dan Pembahasan}

\section{Fungsi Kerukunan Keluarga Kalang (K3) dalam Aspek Sosial}

Awalnya keluarga Kalang di Kecamatan Ambal hanya melakukan kumpulan rutin arisan yang dilaksanakan setiap tanggal 5 (1 bulan sekali). Perkumpulan keluarga Kalang ini awalnya bernama KAB (Keluarga Arisan Bersaudara) tetapi sering disalahartikan dengan Keluarga Arisan Bebojonan. Keluarga Kalang mengubah nama perkumpulannya dengan nama K3 agar tidak disalah artikan lagi. Kerukunan Keluarga Kalang terbentuk dengan dipelopori oleh Mulhadi Pawira Diharja (Alm) yang berasal dari Gombong, Kebumen. K3 (Kerukunan Keluarga Kalang) terbentuk di berbagai daerah, seperti Gombong, Ambal, Petanahan, Puring, Cilacap, Majenang, Maos, Adipala, Kroya, dan Yogyakarta. K3 memiliki logo yang bergambarkan burung memakai mahkota dan blangkon serta membawa obor. Makna dari masing-masing gambar tersebut adalah :

1. Burung : hidupnya menyebar, dimana ada rejeki disitu K3 hinggap; suka berpetualang dan dapat menyesuaikan diri dimana ia tinggal.

2. Obor : tidak mati obornya artinya agar tidak putus tali persaudaraannya; menghidupkan tali persaudaraan.

3. Mahkota : masih ada keturunan darah keraton.

4. Blangkon : K3 tetap meluhurkan adat istiadat budaya jawa. 


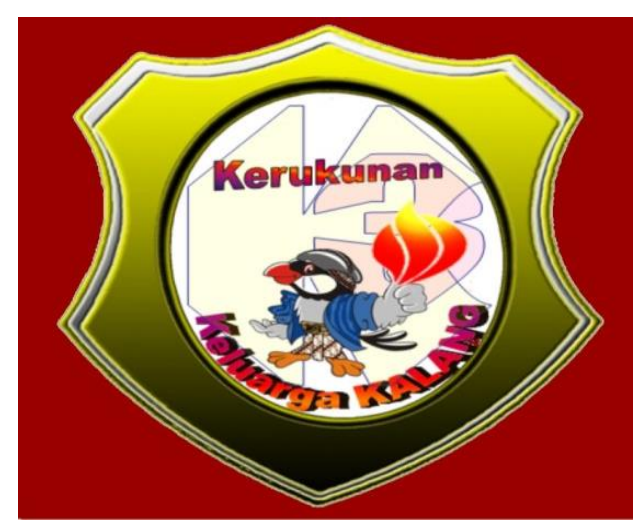

Logo Kerukunan Keluarga Kalang (K3)

Anggota K3 di Kecamatan Ambal yang awalnya melakukan perkawinan endogami yaitu menikah dengan kerabatnya sendiri tetapi sekarang ini banyak yang menikah dengan masyarakat biasa dengan tetap melihat latar belakang status ekonomi keluarga yang akan menjadi pasangannya. Adanya masyarakat Kalang yang menikah dengan masyarakat biasa maka dapat dikatakan bahwa Kalang mempunyai hubungan yang bersifat terbuka dengan masyarakat umum yaitu dengan melakukan perkawinan di luar kerabatnya.

Anggota K3 dan masyarakat secara sosial memiliki hubungan yang bersifat terbuka. K3 membangun masjid untuk kepentingan masyarakat setempat, yaitu membangun 2 masjid di Desa Ambalkebrek dan Desa Pucangan Kecamatan Ambal.

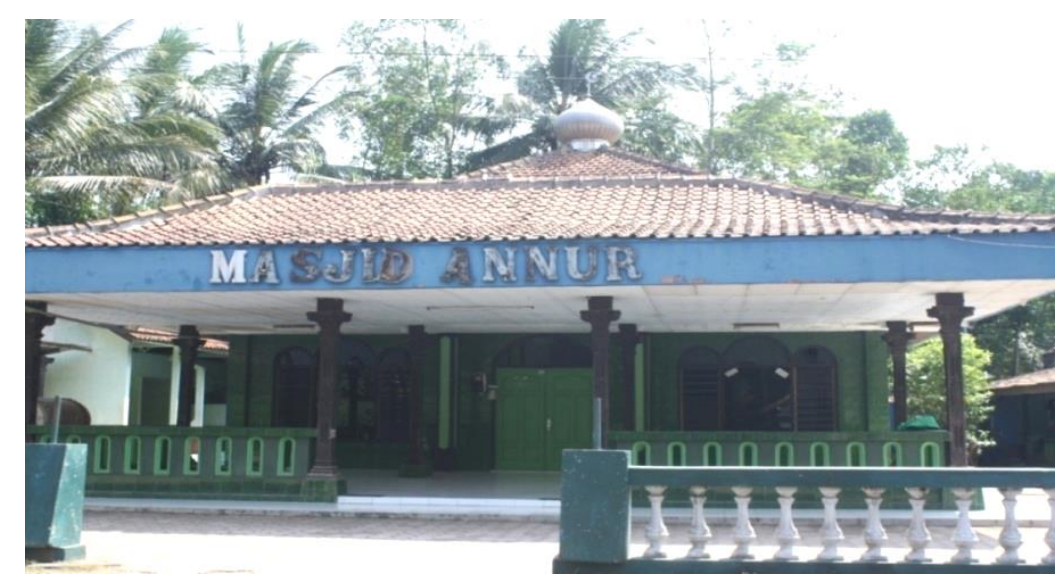

Masjid Ambalkebrek

K3 mengadakan suatu perlombaan yaitu pacuan kuda yang dilaksanakan setiap Lebaran Idul Fitri dengan tujuan untuk lebih mempererat hubungan dengan masyarakat. Peserta yang ikut melombakan kuda banyak yang dari luar daerah seperti Semarang, Solotogo, Surabaya, Blitar, Jogja, Purworejo, Kebumen, Ambal, Pengandaran, dan Cilacap. Perlombaan kuda berlangsung selama 7 hari dan terdapat kelas-kelas di dalamnya, yaitu kelas A sampai kelas F. Untuk kelas A juara pertama mendapatkan uang sebesar 5 juta rupiah, juara kedua mendapatkan uang sebesar 3,5 juta rupiah, dan juara ketiga mendapatkan uang sebesar 2 juta rupiah dan masing-masing mendapatkan 
Tropy. Untuk kelas B, juara pertama mendapatkan uang sebesar Rp 4.000.000,00, juara kedua mendapatkan uang sebesar Rp 3.000.000,00, dan juara ketiga mendapatkan uang sebesar Rp 1.000.000,00, dan seterusnya sampai kelas F.

Anggota K3 mempunyai tradisi yang dapat menjadi hiburan untuk masyarakat setempat, yaitu adanya upacara obong. Kalang melakukan upacara obong apabila ada orang Kalang dari garis keturunan laki-laki meninggal dunia. Upacara obong dilakukan untuk melaksanakan amanat para leluhur masyarakat Kalang supaya anak cucunya menyempurnakan arwah nenek moyangnya. Upacara obong dilakukan dengan membakar puspa (boneka kayu) yang dipercaya memiliki arwah dari orang yang meninggal tersebut. Masyarakat setempat dan segenap tamu secara sukarela memberikan penghormatan ketika puspa dikeluarkan dari dalam rumah dan berjalan bersama menuju tempat pembakaran. Tahapan-tahapan dalam upacara obong sangat menarik perhatian masyarakat dan dapat menjadi hiburan masyarakat setempat.

Anggota K3 di Desa Ambalkebrek ada yang menjadi kepala desa, artinya bahwa anggota $\mathrm{K} 3$ tersebut sudah tidak hanya menjadi anggota $\mathrm{K} 3$ dan anggota masyarakat tetapi juga mempunyai peran dalam melayani masyarakat secara langsung, seperti yang diungkapkan oleh Edi Kusworo (67 tahun) yang merupakan tetangga Kepala Desa Ambalkebrek dan bekerja sebagai petani :

Pak Lurah mau membantu. Jika masyarakat ada keperluan pak lurah mau melayani. Jika ada undangan pak lurah mau datang. Terkadang masyarakat setempat ada yang berhutang untuk keperluan mendadak, pak lurah juga mau memberikan pinjaman (kutipan wawancara, 30 Juli 2011).

Dari hasil wawancara di atas dapat dikatakan bahwa Kepala Desa Ambalkebrek mampu menjalankan tugasnya sesuai dengan harapan masyarakat, yaitu terlihat dari ungkapan kepuasan anggota masyarakat tentang pelayanan Kepala Desanya tersebut. Hubungan sosial antara kalang dengan masyarakat berdifat terbuka karena adanya anggota K3 yang menjabat sebagai kepala desa. Masyarakat tidak segan-segan meminta bantuan kepada kepala desanya yang tidak lain adalah anggota K3, akan tetapi masyarakat dan anggota K3 tetap mempunyai perasaan tidak sederajat, seperti dalam hajatan (mantu). Tri Wahyuni (34 tahun) yang merupakan tetangga anggota K3 di Desa Ambalkebrek menjelaskan bahwa :

Ada kumpulan remaja juga tapi remaja Kalang tidak pernah ikut kumpul. Kalau ada kerja bakti desa Kalang ataupun anggota K3 disini tidak pernah datang tapi ikut berpartisipasi. Berpartisipasinya dengan memberikan rokok atau makanan kecil. Kalau poskamling ya sama saja, tidak pernah datang tapi memberikan rokok atau menyuruh orang untuk mewakili kehadirannya tersebut. Nanti orang yang mewakilinya tersebut akan diberi uang........"mungkin bagi orang Kalang uangnya lebih baik digunakan untuk membeli rokok daripada capek dan tidak bisa mencari uang" (kutipan wawancara, 30 Juli 2011).

Selanjutnya Tri Wahyuni melanjutkan penjelasannya : 
Tidak bersama....tidak dapat berkumpul dengan masyarakat setempat. Ia tersenyum dan mengatakan : "Masyarakat disini yang malu. Misalnya ketika orang Kalang sedang ada hajatan, pasti masyarakat disini mengatakan : " Lah datang ke hajatan sekarang aja lah mumpung sepi belum ada orang Kalang. Saya bertanya : "Bagaimana ketika masyarakat setempat yang mempunyai hajat ?" Ia mengatakan : " ya terserah orang Kalang mau datang kapan. Kecuali pak lurah, Kalang disini kalau datang ke hajatan hanya memberikan amplop dan makan setelah itu langsung pulang (kutipan wawancara, 30 Juli 2011).

Dari hasil wawancara di atas terlihat adanya pembedaan status sosial dalam masyarakat. Anggota K3 tidak pernah hadir dalam kegiatan gotong royong desa atau resik desa tetapi menyuruh orang dari masyarakat setempat untuk menggantikan kehadirannya, kemudian orang tersebut diberi upah seperti rokok atau uang. Masyarakat setempat ketika sedang mempunyai hajat memperlakukan anggota $\mathrm{K} 3$ berbeda dengan masyarakat lainnya. Anggota K3 selalu di punjung (diberi nasi/makanan) ke rumahnya, dan ketika datang ke tempat acara anggota $\mathrm{K} 3$ selalu bergerombol dengan sesama keluarga Kalang, sedangkan untuk masyarakat biasa tidak mendapatkan punjungan, sebaliknya apabila anggota K3 yang sedang ada hajatan maka masyarakat setempat selalu datang pada hari sebelumnya karena masyarakat merasa malu apabila datang ke acara tersebut bertemu dan berkumpul bersama dengan anggota $\mathrm{K} 3$ ataupun dengan keluarga Kalang yang lain.

K3 berusaha untuk menjalin hubungan sosial dengan masyarakat sesuai dengan teori Fungsionalisme yang dikemukakan oleh Malinowski, bahwa bagian-bagian dari organisme saling berhubungan dan untuk tetap bertahan maka kebutuhan sistem tersebut harus terpenuhi. Masyarakat yang memiliki kebutuhan akan adanya fasilitas desa dapat terpenuhi dengan adanya bantuan dari anggota K3 tersebut, kebutuhan masyarakat akan adanya layanan yang sesuai harapan masyarakat terpenuhi oleh anggota K3 yang menjabat sebagai Kepala Desa tersebut, selanjutnya adanya pacuan kuda dan upacara obong dapat menjadi hiburan masyarakat. Anggota K3 memiliki kebutuhan sendiri dalam hubungan sosial tersebut yaitu kebutuhan akan adanya pengakuan dan penghormatan dari masyarakat. Dari semua unsur-unsur tersebut di atas masing-masing saling terikat dan mempengaruhi.

K3 mempunyai beberapa kegiatan rutin yang dilakukan untuk mempererat tali persaudaraan di antara anggota K3 salah satunya adalah arisan. K3 melakukan arisan yang dilaksanakan setiap tanggal 5 sekitar pukul 20.00 WIB dan tempat arisan digilir setiap bulannya. Arisan K3 dihadiri oleh masing-masing kepala keluarga. Setiap anggota ditarik iuran untuk arisan Rp 25.000,00 dan Rp 3.000,00 per bulan untuk iuran makanan yang akan disajikan. Antar anggota K3 menjadi lebih dekat dan akrab karena selama proses arisan berlangsung anggota dapat saling menyapa, bertukar cerita mengenai keluarga dan bisnis, serta hal-hal yang tidak sempat dibicarakan dengan adanya kesibukan anggota K3 masing-masing. 


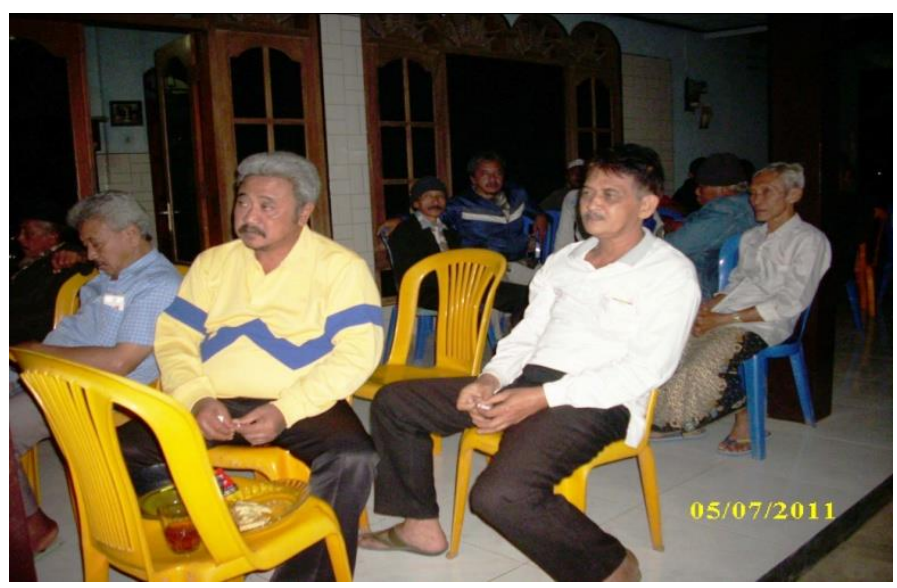

Anggota K3 di Acara Arisan

Kerukunan Keluarga Kalang (K3) selalu mengadakan acara silaturahmi atau Halal Bi Halal setiap Hari Raya Idul Fitri. K3 yang dapat mengumpulkan semua keluarga kalang dalam acara silaturahmi tersebut maka sesuai dengan tujuan K3 yaitu "ngumpulke balung pisah". Silaturahmi biasanya dilakukan K3 tidak hanya antar keluarga K3 Ambal tetapi juga antar K3 di semua daerah.

Anggota K3 berasal dari kelas yang berbeda-beda menurut mata pencaharian. Kelas sosial menurut mata pencaharian ini kemudian menimbulkan perbedaan pendapatan keluarga K3 masing-masing. Perbedaan pendapatan keluarga K3 menjadikan perbedaan status masing-masing anggota. Sikap atau hubungan antar anggota K3 juga terpengaruh dengan kelas sosial tersebut. Umumnya anggota K3 masih bergerombol apabila menghadiri acara tertentu.

Kalang di Kecamatan Ambal tidak semuanya ikut menjadi anggota K3 dengan beraneka macam alasan, seperti yang diungkapkan oleh oleh Juliah (36 tahun) yang menjadi ibu rumah tangga : "Ya saya malu. Ia tersenyum dan mengatakan : " saya tidak punya apa-apa. Ya tapi meskipun saya tidak ikut K3 kalau ada acara keluarga saya juga datang" (kutipan wawancara, 30 Juli 2011). Selanjutnya saya bertanya kepada ketua K3 yaitu Sugeng Diyono (50 tahun) tentang permasalahan ini. Sugeng Diyono mengatakan bahwa : " Memang ada beberapa keluarga Kalang disini yang tidak ikut K3. Tindakannya ya sudah ada. Kalau ada perkumpulan K3 semua keluarga Kalang disini saya bagikan undangan tetapi masih ada yang tidak datang“. Kalang di Kecamatan Ambal tidak semuanya masuk menjadi anggota K3 karena kendala waktu, jarak, atau alasan lainnya. Kalang di Kecamatan Ambal yang tidak ikut menjadi anggota K3 tidak semuanya memiliki ekonomi yang pas-pasan. Terdapat kesalahpahaman antara pandangan masyarakat mengenai K3 karena masyarakat menilai semua anggota K3 memiliki tingkat ekonomi yang tinggi, akibatnya masyarakat mempunyai rasa minder dan malu apabila bersama dengan anggota K3.

Anggota K3 di Kecamatan Ambal mempunyai tempat tinggal yang saling berdekatan sehingga intensitas anggota K3 lebih banyak bersama. Terdapat persaingan dalam menjalankan bisnis karena antar keluarga K3 memiliki usaha yang sama tetapi 
dapat diatasi dengan adanya kerjasama seperti membeli bahan baku kepada saudara sendiri.

Kerukunan Keluarga Kalang (K3) memiliki dana social yaitu dana hasil iuran kas tiap bulannya yang digunakan untuk makam, kematian, dan tratag. Jika ada anggota K3 yang meninggal, membutuhkan tratag (membuat atap ketika ada hajatan / kematian), atau ngijing (membuat makam) maka uang kas ini dapat digunakan.

Konsep kekerabatan mempengaruhi terbentuknya K3 dan hubungan yang diciptakannya dengan masyarakat setempat. K3 belum mampu sepenuhnya memenuhi kebutuhan ekonomi dan sosialnya karena itu K3 membutuhkan kerjasama dengan masyarakat di luar kerabatnya. Masyarakat umum dijadikan tenaga kerja untuk menjalankan usaha-usaha K3. Konsep kekerabatan priyayi yang disebutkan Koentjaraningrat bahwa apabila seseorang mengalami kesukaran keuangan maka saudara kandung wajib membantu. Konsep ini mempengaruhi K3 yaitu dengan dibentuknya arisan, dana sosial, koperasi, dan kerjasama dalam menjalankan bisnis ekonominya.

\section{Fungsi Kerukunan Keluarga Kalang (K3) dalam Aspek Ekonomi}

Kalang di Kecamatan Ambal bergelut dalam usaha home industri seperti emping mlinjo, kecap, gula jawa, dan usaha kecil lainnya. Keluarga Kalang secara turuntemurun mewariskan strategi berdagang kepada anak hingga cucunya dengan cara mengajak berdagang dan mengolahnya sendiri. Terdapat usaha yang paling dominan, yaitu usaha emping karena bahan untuk membuat emping ini sangat mudah didapatkan dan murah. Produksi biji mlinjo menjadi emping dilakukan di rumah masing-masing pekerja dan diberi waktu 3 hari untuk menyelesaikan produksinya tersebut. Pekerja menyerahkan emping mentah yang sudah di produksinya dan akan dihargai oleh majikan setiap $10 \mathrm{~kg}$ adalah Rp 20.000,00. K3 memiliki buruh emping musiman, yaitu ketika sedang musim emping atau emping sedang mahal masyarakat dipekerjakan lebih banyak dari sebelumnya. Masyarakat setempat selain menjadi buruh juga banyak yang menjadi pembantu rumah tangga. Berikut merupakan rincian jumlah tenaga kerja anggota K3 Desa Ambalkebrek :

\begin{tabular}{clc}
\hline No & \multicolumn{1}{c}{ Pekerjaan } & Jumlah \\
\hline 1. & Buruh Tetap & 35 \\
\hline 2. & Buruh Musiman & 150 \\
\hline 3. & Sopir & 9 \\
\hline 4. & Kernet & 9 \\
\hline & Pembantu Rumah & \\
5. & Tangga & 6 \\
\hline & Total & 209 \\
\hline
\end{tabular}


Satemi (55 tahun) yang bekerja sebagai pembantu rumah tangga mengatakan :

Dahulu waktu masih remaja saya sudah ikut di rumahnya Noto Semito (Alm) kurang lebih 1 tahun. Selanjutnya saya berhenti bekerja di rumahnya Noto, saya akhirnya jadi buruh emping (nuthuk). Saya jadi buruh emping di rumahnya Mbah Glondong. Lha terus setelah Mbah Glondong meninggal saya disuruh untuk bekerja di sini sebagai pembantu rumah tangga. Saya bertanya : "Berarti sudah berapa lama ibu bekerja di tempat Mbah Glondong ?” Ia mengatakan : “iya semenjak saya remaja berarti sudah 36 tahun yang awalnya saya hanya menjadi buruh emping kemudian saya menjadi pembantu rumah tangga sampai sekarang (kutipan wawancara, 30 Juli 2011).

Dari hasil wawancara di atas, dapat dikatakan bahwa pekerja anggota K3 ini seperti berada di dalam sebuah lingkaran yang lingkupnya hanya K3. Apabila suatu ketika seorang pekerja berhenti bekerja pada majikannya dan ingin bekerja di tempat lain maka meskipun dia bekerja di tempat lain, majikan barunya tersebut masih satu keluarga dengan majikan sebelumnya (sama-sama anggota K3). Anggota K3 tidak akan melepas pekerjanya yang rajin dan ulet, meskipun pekerjanya itu harus keluar maka dia hanya akan bekerja di tempat saudara majikannya (sama-sama orang Kalang). Pekerja K3 tidak hanya menerima upah per bulan dari majikan tetapi juga penghasilan harian dari hasil penjualannya tersebut. Keuntungan dari penjualan tersebut dibagi rata dengan majikannya karena penanaman saham bersama tersebut, apabila ada kerugian juga akan ditanggung bersama. Pekerja menggunakan penghasilannya untuk membeli sawah dan hewan ternak. Terdapat unsur-unsur yang terkait dan saling mempengaruhi yaitu tenaga kerja, upah, dan lapangan kerja maka hal ini sesuai dengan teori fungsionalisme Malinowski.

\section{Pentingnya Koperasi K3 untuk Relasi dan Pertukaran antara Pihak Patron Kalang dan Klien Masyarakat}

Anggota K3 mempunyai Koperasi Simpan Pinjam yang anggotanya khusus keluarga Kalang. K3 melakukan kegiatan koperasi setiap tanggal 5 bersamaan dengan kegiatan arisan K3. Koperasi K3 sudah berbadan hukum sejak tanggal 21 Desember 2005, yaitu dengan nomor 518.08/09/BH/2005. Koperasi K3 dibangun untuk membantu ekonomi lemah, membangun solidaritas, dan agar orang Kalang yang menikah dengan orang biasa tidak termarginalisasi atau terpinggirkan. $\mathrm{K} 3$ terkendala dana dan beberapa persyaratan untuk memiliki tanah dan kantor sendiri belum dapat dipenuhi K3 sehingga koperasi masih berbentuk sekretariat. Sekretariat koperasi K3 berada di rumah Sugeng Diyono selaku ketua K3.

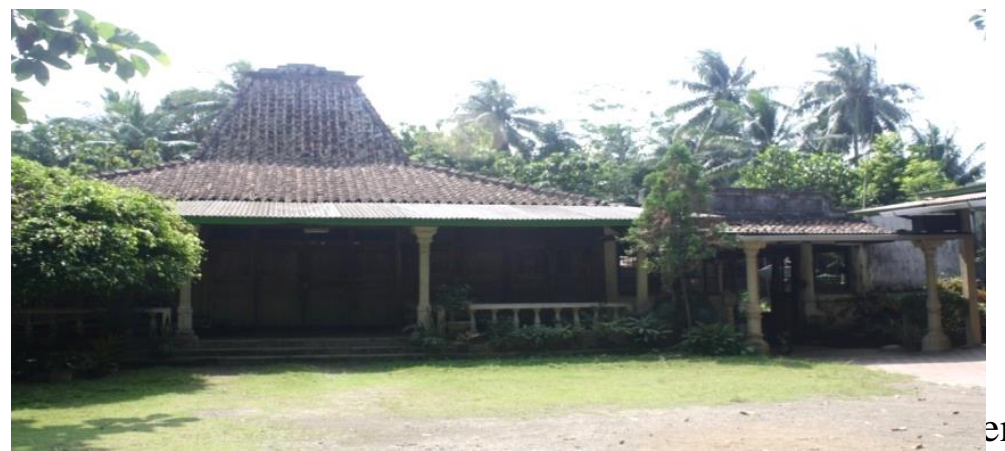




\section{Sekretariat Koperasi K3}

Anggota menyerahkan uang untuk angsuran pokok, iuran wajib, dan SHR (Simpanan Hari Raya) kepada masing-masing anggota K3 yang sudah ditugaskan untuk memegang dana itu. Anggota K3 mempunyai beberapa bendahara yang masing-masing mempunyai tugas yang berbeda. Ada yang memegang uang arisan, ada yang memegang simpanan wajib, ada yang memegang iuran wajib, dan ada yang memegang iuran sukarela. Simpanan wajib setiap anggota adalah Rp 100.000,00 untuk iuran wajib sebesar Rp 15.000,00 dan untuk iuran sukarela tidak ada batasan uang, sedangkan bunga dari setiap pinjaman di koperasi adalah $1 \%$.

Uang yang akan dipinjam kepada anggota adalah total dari jumlah dana angsuran pokok, perolehan bunga, iuran wajib, SHR (Simpanan Hari Raya), dan saldo bulan sebelumnya. Anggota koperasi K3 tidak dapat meminjam uang apabila tidak pada tanggal 5 karena dana yang untuk dipinjamkan langsung habis dibagikan kepada anggota.

K3 mempunyai cara tersendiri dan unik untuk mendorong anggotanya agar rajin menyerahkan uang sukarela atau ya.ng dapat dibilang uang SHR (Simpanan Hari Raya), seperti yang diungkapkan oleh Sugeng Diyono (50 tahun) selaku ketua K3 :

Ada SHR atau iuran sukarela, untuk yang rutin mengangsur ada dorprisenya untuk ranking 1, 2, dan 3. Hari raya tahun lalu saya menjadi juara 2. Itu saja saya sudah ngangsur tiap bulannya memberikan uang Rp 75.000,00. Yang menjadi juara 1 tiap bulannya memberikan uang $\mathrm{Rp} 85.000,00$ dan kadang $\mathrm{Rp}$ 100.000,00. Sekarang saya memberikan uang Rp 100.000,00 tiap bulannnya agar bisa jadi juara 1 besok lebaran (kutipan wawancara, 23 Juli 2011).

K3 memiliki cara untuk memberikan motivasi kepada anggotanya agar rajin mengangsur khususnya iuran sukarela yaitu dengan memberikan dorprise. Pemenang 1, 2, dan 3 akan diberikan dorprise berupa sarung, baju, dll. K3 akan mengumumkan anggota yang mendapatkan dorprise ketika Hari Raya Idul Fitri. Seseorang dapat dijadikan pemenang apabila mengangsur tiap bulannya rutin dan sama besarnya, misalnya Rp 50.000,00 bulan depannya Rp 85.000,00 dan bulan depannya lagi Rp 100.000,00, akan tetapi anggota ada juga yang macet mengangsur hutang dan akhirnya jarang datang dalam pertemuan rutin K3. K3 memberikan teguran kepada anggota yang belum dapat mengangsur hutangnya.

Masyarakat tidak dapat menjadi anggota koperasi K3 tetapi masih dapat menikmati manfaat secara tidak langsung meskipun layanan koperasi K3 khusus untuk keluarga Kalang. Anggota K3 menggunakan layanan simpan pinjam koperasi untuk menambah modal dan memperluas usahanya. Anggota koperasi K3 mempunyai usaha wiraswasta yang juga menyediakan lapangan kerja bagi masyarakat setempat. Masyarakat bekerja dengan K3 sebagai buruh, pembantu rumah tangga, sopir, dan kernet. Umumnya pekerja K3 ini bekerja dengan waktu yang relatif lama, seperti yang diungkapkan Satemi (55 tahun) : 
Saya janda mempunyai anak 7 sekarang sudah keluarga semua.....Lha bagaimana lha pondoknya. Karangan saya kepunyaan kepunyaan sini (majikan). Saya bertanya : "Karangan bagaimana maksudnya buk ?" Ia menjawab :" Saya kan tidak punya apa-apa. Tidak punya karangan (tanah), tidak punya sawah, cuma mondok. Jadi saya ya disini terus. Ia menunjuk ke belakang rumah majikannya dan berkata :"Rumahnya saya ya belakang sini. Satu tanah dengan majikan saya. Saya bertanya :'Majikan ibu sering membantu ibu?" Ia menjawab:"Ya iya....kalau ada apa-apa saya ya pasti diberi. Kalau ada kekurangan modal saya ya dibantu. Saya ya sering dikasih beras. Kalau ada saudara sini dari Jogja atau Jakarta saya ya pasti dikasih uang. Tetapi untuk membangun rumah saya berusaha untuk membangun sendiri (kutipan wawancara, 30 Juli 2011).

Dari ungkapan di atas, dapat dikatakan bahwa keberadaan anggota K3 di masyarakat sangat diharapkan peranannya. K3 dengan usahanya telah memberikan kesempatan kepada masyarakat untuk mendapatkan pekerjaan. Masyarakat sangat membutuhkan upah untuk memenuhi kebutuhan ekonominya. Masyarakat tidak hanya sekedar menjadi buruh, pekerja sering mendapatkan sesuatu yang tidak hanya sekedar upah. Di luar hubungan kerja dengan majikannya, keluarga pekerja pun mendapatkan perlakuan yang baik, seperti yang diungkapkan oleh Satemi di atas, majikannya telah memberikannya sebidang tanah yang dapat untuk membangun rumah meskipun masih satu lahan dengan majikannya. Satemi mengaku dirinya bukanlah orang yang mampu, akan tetapi setelah Satemi bekerja menjadi buruh di tempat majikannya itu, banyak yang telah majikannya berikan kepadanya. Satemi ketika kekurangan modal, majikannya bersedia meminjamkan uang dan dilunasi dengan memotong gaji. Selanjutnya menurut Saringan (50 tahun) yang merupakan buruh tetap sebagai pengepul gula jawa :

Majikan saya pernah hutang kepada saya. Ya tapi majikan saya pasti mengembalikan. Saya tidak pernah hutang dengan majikan saya. Kalau buruh yang lain ya sering hutang tapi kalau saya tidak pernah. Tapi kalau kepepet ya pernah tapi jarang. Saya ya pernah ingin keluar dari sini tapi saya tidak enak. Masalahnya sudah lama disini. Majikan saya itungan tapi saya bisa maklum. Saya kalau tidak berangkat juga majikan saya ke rumah saya terus. Tidak berangkat satu hari saja saya sudah didatangi ke rumah berulang kali (kutipan wawancara, 23 Juli 2011).

Dari kedua ungkapan di atas, dapat dikatakan bahwa majikan dan bawahannya saling membutuhkan. Buruh terkadang meminjam uang kepada majikannya tetapi majikan juga terkadang meminjam uang kepada buruhnya. Majikan dan buruh saling membutuhkan, yaitu membutuhkan upah dan tenaga kerja. Buruh dapat menerima kekurangan yang dimiliki majikannya, berarti antar keduanya sudah mempunyai hubungan yang sangat dekat sehingga antar keduanya sudah saling mengenal dan menerima kekurangan masing-masing.

Dari semua uraian di atas, terlihat terdapat hubungan timbal balik antara majikan dengan bawahannya. Hubungan timbal balik antara majikan dan buruhnya lama- 
kelamaan tidak hanya sekedar hubungan antara majikan dengan bawahan tetapi lebih kepada rasa saling memahami dan bahkan saling menganggap sebagai keluarga sendiri. Anggota K3 dengan buruhnya memiliki hubungan yang tercipta dengan adanya koperasi K3. Apabila semua anggota dapat mengembangkan usahanya maka anggota K3 juga akan membutuhkan tenaga kerja yang lebih banyak dari sekarang, sedangkan apabila anggota K3 mengalami kesulitan dana dan tidak dapat mengembangkan usahanya maka hubungan antar majikan dengan bawahannya akan berhenti karena majikan tidak dapat memberikan upah maka dapat dikatakan koperasi K3 memiliki peran penting dalam terciptanya hubungan antara kedua belah pihak yaitu anggota K3 dengan pekerjanya. Adanya hubungan antar majikan dengan pekerjanya yang lamakelamaan dapat menimbulkan kekeluargaan maka hal ini sesuai dengan teori patron klien. Teori Patron Klien mengungkapkan bahwa terjadi hubungan antar individuindividu yang berbeda status sosial ekonominya yaitu pihak yang satu lebih banyak memberi dan pihak yang lain banyak menerima.

\section{Kesimpulan}

K3 memberikan keuntungan secara sosial dan ekonomi kepada masyarakat. K3 secara sosial melakukan hubungan dengan masyarakat setempat dan sesama keluarga K3. K3 dengan masyarakat setempat melakukan perkawinan campur yang sebelumnya tidak dilakukan oleh keluarga K3, K3 memberikan beberapa fasilitas (masjid) dan hiburan (lomba pacuan kuda dan tradisi obong), serta anggota K3 yang menjadi kepala desa. K3 dengan sesama keluarga K3 melakukan kegiatan yang dapat memberikan keuntungan dan menjalin solidaritas seperti kegiatan arisan bulanan K3, acara rutin Halal Bi Halal, dana sosial K3 untuk keluarga K3 (tratag, dana makam, dan dana kematian), dan kerjasama ekonomi.

K3 memberikan keuntungan kepada masyarakat secara ekonomi dengan memberikan lapangan kerja. Anggota K3 mempunyai bisnis wirausaha yang banyak menggunakan tenaga kerja dari masyarakat setempat sehingga masyarakat menjadi memiliki mata pencaharian beragam seperti buruh, sopir, kernet, pembantu rumah tangga, dll. K3 membentuk koperasi juga membawa manfaat secara tidak langsung kepada masyarakat khususnya yang menjadi tenaga kerja K3. Masyarakat bekerja sebagai tenaga kerja K3 karena adanya kebutuhan ekonomi, bukan karena nrimo ing pandum.

K3 mengalami beberapa masalah yang perlu dicari solusinya. K3 memiliki masalah seperti dana K3, dan administrasi koperasi K3. K3 membutuhkan dana cukup banyak untuk mempunyai tanah dan membangun kantor koperasi K3. K3 mengalami kesulitan dalam pengumpulan dana karena jumlah anggota yang masih sedikit. K3 juga mengalami masalah dalam administrasi koperasi. K3 tidak memberikan aturan yang tegas kepada anggota yang meminjam uang di koperasi dan anggota yang tidak mengangsur hutangnya hanya mendapatkan teguran karena itu administrasi koperasi menjadi tidak tertib. 
Putri Anggraeni

\section{Bibliografi}

Ahimsa-Putra, Heidy Shri, dkk. 2003. Ekonomi Moral, Rasional dan Politik dalam Industri Kecil di Jawa: Esei-Esei Antropologi Ekonomi. Yogyakarta : Kepel Press.

Ahimsa-Putra, Heidy Shri. 2007. Patron \& Klien di Sulawesi Selatan Sebuah Kajian Fungsional-Struktural. Yogyakarta : Kepel Press.

Amini, Mutiah. 2006. Dari Poro Hingga Paketik: Aktivitas Ekonomi Orang Kalang di Kotagede pada Masa Depresi-1930. Jurnal Humaniora, Volume 18 No. 2 Juni 2006. url : http://i-lib.ugm.ac.id. (14 mei 2011).

Brata, Nugroho Trisnu. 2008. PT.Freeport \& Tanah Adat Kamoro Kajian Teori-Teori Antropologi. Semarang: UNNES Press.

Badan Pusat Statistik (BPS) Kabupaten Kebumen. 2010. Kecamatan Ambal dalam Angka. Kebumen : BPS.

Endraswara, Suwardi. 2006. Metodologi Penelitian Kebudayaan. Yogyakarta: Gadjah Mada University Press.

Geertz, Clifford. 1989. Abangan, Santri, Priyayi dalam Masyarakat Jawa. Jakarta : PT.Dunia Pustaka Jaya.

Hariyono, M.T.P. 2009. Ilmu Sosial dan Budaya Dasar. Semarang: Mutiara Wacana.

Ihromi, T.O. 1980. Pokok-Pokok Antropologi Budaya. Jakarta: Yayasan Obor Asia.

Kaplan, David dan Robert A. Manners. 2002. Teori Budaya. Yogyakarta: Pustaka Pelajar.

Koentjaraningrat. 1987. Sejarah Teori Antropologi I. Jakarta: UI Press.

Pelly, Usman dan Asih Menanti. 1994. Teori-Teori Sosial Budaya. Jakarta: Depdikbud.

Poloma, Margaret M. 1984. Sosiologi Kontemporer. Jakarta : Rajawali.

Ritzer, George. 2002. Sosiologi Ilmu Pengetahuan Berparadigma Ganda. Jakarta: Rajawali Press. 
Fungsi Kerukunan Keluarga Kalang (K3) Dalam Aspek Sosial Ekonomi Di Desa Ambalkebrek Kecamatan Ambal

Rudito, Bambang. 2011. Pranata Sosial. url: http://www.google.co.id/ search?q= pengertian+sosial+ekonomi\&ie $=u t f-8 \& o e=u t f-8 \&$ aq=t\&rls=org.mozilla:enUS:official\&client=firefox-a. (3 januari 2012).

Sadikin. 2006. Sekilas Tentang Ekonomi Moral Dan Rasional. url: http://rumah kiri.net/index.php.com. (18 April 2011).

Salim, Agus. 2001. Priyayi Jawa sebagai Kelas Menengah dalam Stratifikasi Sosial Modern. Semarang : Badan Perencanaan Pembangunan Daerah Propinsi Jateng.

Suparlan, Parsudi. 1993. Kemiskinan di Perkotaan. Jakarta : Yayasan Obor Indonesia.

Turner, Jonathan H dan Alexandra Maryanski.2010. Fungsionalisme. Yogyakarta: Pustaka Pelajar.

Warto. 2011. Aspek-Aspek Sosio-Historis Komunitas Kalang di Jawa. url: warto.staff.fs.uns.ac.id/2011/10/20/kalang/. (3 januari 2012). 